Globish (An English-Indonesian journal for English, Education and Culture)

Vol. 9 No.1 January 2020

P-ISSN: 2301-9913, E-ISSN: 2597-9132

DOI: http://dx.doi.org/10.31000/globish.v7i2

\title{
Improving the Students' Speaking Skill Through Snakes and Ladders (SI) on Second Semester Students of English Study Program at Stain Bengkalis
}

\author{
Rini Fitria ${ }^{1}$ Ervina ${ }^{2}$ \\ 1,2English Education Study Program of STAIN Bengkalis
}

\begin{abstract}
The aim of the research was to describe the learning atmosphere during the implementation of "Snakes and Ladders" in teaching Speaking. Besides, the research was also designed to know how the improvement of the students' Speaking skill during the implementation of "Snakes and Ladders". This research was a classroom action research. The participants of this research were 27 second semester students of English Study Program at STAIN Bengkalis. This research was conducted in two cycles by following the procedure of action research, i.e. planning, implementing, observing, and reflecting. In collecting the data, the researcher used observation, questionnaire, and test. The lecturer was the researcher assisted by collaborator as observer. The questionnaire was given to the students before and after the implementation of "Snakes and Ladders". The tests were in the form of pre-test, post-test 1 and post-test 2 . The data were analyzed qualitatively and quantitatively. The qualitative data were analyzed using Interactive Model of Data Analysis as propounded by Matthew M. Miles and A.M. Huberman. The results of the research showed that the learning atmosphere also improved. The class became more active and confident. Furthermore, "Snakes and Ladders" was able to improve the students' Speaking Skill. It was proven by the increase of the students' mean score from 41.16 in pre-test to 46.21 in cycle 1 , and 48.98 in cycle 2 , although the results of the research were just a little bit improvement. It could be concluded that the use of "Snakes and Ladders" has proven to be an effective way in teaching-learning of Speaking Skill on Second Semester of English Study Program at STAIN Bengkalis.
\end{abstract}

Keyword: Speaking Skill, Snakes and Ladders

\section{Introduction}

Language is a means of communication. People cannot convey their ideas and feeling without language. There are two kinds of language skills; productive skills and receptive skills. The productive skills are writing and speaking, and the receptive skills are reading and listening. In relation with teaching and learning process, one of those skills which have to be mastered by the students is speaking.

According to Luoma (2004: 20) teaching and testing experts often talk about speaking as a technical term to refer to one of several skills those language learners should develop and have. In this case, they should be able to speak with others such as classmates and teachers. Speaking is very important for students in learning a language because someone purposes in learning a language is to be able to communicate the language. Brown (1994) in Celce and Murcia (2001: 103) mentions that there are a number of features that make speaking challenging as a language skill. He describes that fluent speech contain

Received September 25, 2019; Revised Oktober 25, 2019; Accepted November 28 2019 
P-ISSN: 2301-9913, E-ISSN: 2597-9132

DOI: http://dx.doi.org/10.31000/globish.v7i2

reduced forms such as constructions, vowel reduction, and elision by which learner who are not exposed and do not get sufficient practice with them will retain their rather formalsounding full form. He also states that learners should also recognize and acquire slang and idiom, beside stress, rhythm, intonation in speech. Fail in having those aspects in speaking, he utters, learners will produce sound bookish in their speech.

In teaching speaking, lecturer/teacher should be able to guide students into learning situation in order to enable them to master it because speaking is the key of communication. Therefore, the lecturer's position with his or her ability, readiness, and proficiency are also useful for the students. Students need to recognize that speaking involves some components, such as pronunciation, grammar, vocabulary, interaction, turn taking, and rate of speech. Every student must learn those components, because both of parts have an important role to the others to have good proficiency. Learning one of the components must be supported by learning the others.

To improve the speaking skill, there are many methods or techniques which can be applied. One of them is Snakes and Ladders. Kusrini (2012;4) states that Snakes and Ladders board game facilitates them to learn about counting, life, interaction, and socialization in speaking.

\section{Literature Review}

\section{Speaking}

According to Brown (1994: 29), communicative competence is the goal of a language classroom. It can be inferred that speaking such a communicative competence as a goal of language learning includes social context. Besides that, Nunan (2013) in Pratama and Satria (2016) defines that speaking is the productive oral skill, it consists of producing sysmatic verbal utterances to convey meaning. Thornbury (2005: 2-14) suggests various areas of speaking to describe different speaking events which have transactional and interpersonal functions. Transactional function refers to purpose of conveying information and facilitating the exchange of goods and services, whereas interpersonal function refers to all about maintaining and keeping good relations between people.

Brown (2007: 328) elaborates that skills in speaking involve micro-skills and macroskills. They are micro and macro skill. Micro skill suggests the importance of focusing on both the forms of language and the functions of language. Macro skill is concerning about the individual processes in learning language.

The objective of teaching speaking skills is communicative efficiency. Learners should be able to make themselves understood, using their current proficiency to the fullest. They should try to avoid confusion in the message due to faulty pronunciation, grammar, or vocabulary, and to observe the social and cultural rules that apply in each communication situation (http://www.nclrc.org/essentials/speaking/goalsspeak.htm). To help students develop communicative efficiency in speaking, instructors can use a balanced activities approach that combines language input, structured output, and communicative output. To find out the results of the treatment, assessment test will be given. Testing speaking can be done at the beginning and at the end of most language courses, as well as various times during the course itself the activities designed to test speaking are the same as the activities to practice speaking (Thornbury, 2005: 124). The assessment can be done using a scoring rubric. 
A scoring rubric is a set of guidelines for applying performance criteria to evaluate the students' responses and performance which consists of verbal descriptions of the students' responses and performance (Linn and Groniund, 2000; 270).

In assessing speaking using a scoring rubric, they are a holistic scoring and an analytic scoring. The holistic scoring is a quick scoring in which students are scored based on an overall impression. The assessment involves more than one scorer. Then, the differences in scoring should be discussed and negotiated. The analytic scoring is a longer scoring but is more reliable and fairer. Here, students are scored based on a variety for criteria or categories.

The assessment criteria or categories are: (1) grammar. Students are scored for their accuracy and appropriateness in using grammar; (2) vocabulary. Students are scored for their ability in using vocabularies or English equivalents in utterances or sentences; (3) pronunciation. The focus of assessment is on the accuracy of the students in pronouncing words with good intonation and stress; (4) fluency. Students are scored for their ability to perform speech fluently; (5) comprehension. The focus of assessment is on students' competence to comprehend other persons talking in simple descriptive or transactional text. (Thornbury, 2005: 127).

2. Snakes and Ladders Board Game

According to Salen and Zimmerman (2003) in Simbolon and Satria (2016) a game is a system in which players engage in an artificial conflict, defined by rules, that produces measurable results. A board game is a game that can be easily modified by the game designer. The designer can create and modify the game according to the needs. The Snakes and Ladders board game is one kind of a board game that widely known by the people. It is a popular game that can facilitate the students to learn language. The Snakes and Ladders board game facilitates them to learn about counting, life, interaction, and socialization in speaking (Kusrini,2012;4). A ladder provides a short cut to a square nearer the "Finish" square and a snake obligates the players to return to a square nearer the "Start" square. In this game, the students can learn about up and down in life or about joys and troubles. The ladders represent "the up life and joy" while the existence of the snakes represent "the down in life or trouble" (Sari and Muniroh, 2012).

There are some materials in playing the Snakes and Ladders board game. They are counters, dice, game board, and cards (Porenzo via Rahmawati: 2012). The counter will be used as a marker for a player to be put on the board. The counter can be stone, seeds, plastics counters, or buttons. The dice is a small-six cube with one to six dots on its side. However, the researcher modified the dice into the six-cube with the one to four dots on its side. The dice will decide how many steps the players will move. The game board is where the players move the counter. The track of the game consists of some squares that start from "Start" and end on "Finish". While playing the game, the players will find ladders and snakes. On each square of the game they need to take a card containing clue or expression that they need to use. The one who reaches the "Finish" square is the winner.

The Snakes and Ladders board game for language teaching has the same rules with a regular Snakes and Ladders board game but in this game, there are some modifications to make the students to be able to communicate using English. Below are the rules of the Snakes and Ladders board game based on Haryati (2012: 36) with some modifications.

1) Put your playing piece on the start square.

2) Decide who is going to start and which order you are going to play.

Improving the Students' Speaking Skill Through

Snakes and Ladders (Sl) on Second Semester

Students of English Study Program at Stain Bengkalis

Rini Fitria1 Ervina 2 
P-ISSN: 2301-9913, E-ISSN: 2597-9132

DOI: http://dx.doi.org/10.31000/globish.v7i2

3) First player rolls the dice and moves forward according the number of the dice.

4) Answer the question according to the number of the square indicates.

5) Speak aloud the answer.

6) Continue the playing, roll the dice again.

7) Player gets snakes; turn off from the snake tip until the snakes' tail.

8) Player gets ladders; turn on from bottom of the ladder until top of the ladder.

9) To finish you have to land directly on the square last square.

Implementing the Snakes and Ladders Board Game for Speaking Activity; It needs an extra effort to apply the Snakes and Ladders board game in the class. There are some steps that the researcher needs to do to be able to make the teaching and learning process run effectively so the basic competence will be achieved in the end of the class. First, the researcher prepares the equipment of the game such as the game boards, dices, rules, and counters for each group. Second, the researcher needs to explain the rules of the game. The researcher has to make sure that the students really understand the rules of the game. If it is necessary, the researcher can demonstrate the game with some students in front of the class. Third, the researcher divides the students to work in the groups of six. Fourth, each of the students takes turns to roll the dice and the one who gets the highest number will go first and decides order of the players. The first player rolls the dice and moves to the next square according to the number that the dice indicates. For example, if the player gets the two dots in the dice, the player moves two steps from the "Start" square. the fifth, the students have to answer every questions and instructions in every square. The last, the one who reaches the "Finish" square first win the game.

\section{Methodology}

1. Research Type and Design

Classroom action research is a method of finding out what works best in lecturers' own classroom so that they can improve students' learning. Many lecturers practice personal reflection on teaching, others conduct formal empirical studies on teaching and learning. Classroom action research is more systematic than personal reflection but it is more informal and personal than formal educational research.

Action research is classroom-based research conducted by lecturers in order to reflect upon and evolve their teaching; it is a systematic, documented inquiry into one aspect of teaching and learning in a specific classroom. The purpose of lecturer research is to gain understanding of teaching and learning within one's classroom and to use that knowledge to increase teaching efficacy student learning. Reflective lecturers do this every day, only not as carefully and systematically. By and large, classroom action research is a reflective process which helps lecturers to explore and examine aspects of teaching and learning and to take action to change and improve.

This research applies the principles of action research. The design of this kind of research was based on the spiral model suggested by Kemmis and McTaggart (2005:4). The researcher plan, act, observe and reflect on the students' speaking skill through Snakes and Ladders.

a. Plan

Before using the method, a researcher must prepare the lesson plan, material, media, time, schedule and instrument in order that researcher can design the materials what will be as learning process as possible.

b. Action 
Researcher gives explanation about the materials and gives treatment with Snakes and Ladders. The process of teaching using Snakes and Ladders begins.

1) Put your playing piece on the start square.

2) Decide who is going to start and which order you are going to play.

3) First player rolls the dice and moves forward according the number of the dice.

4) Answer the question according to the number of the square indicates.

5) Speak aloud the answer.

6) Continue the playing, roll the dice again.

7) Player gets snakes; turn off from the snake tip until the snake's tail.

8) Player gets ladders; turn on from bottom of the ladder until top of the ladder.

9) To finish you have to land directly on the square last square.

\section{c. Observation}

In this step, the researcher as the practitioner implemented Snakes and Ladders in the teaching and learning process, and the English lecturer as the collaborator observed students' understanding, participation and activities in the teaching and learning process. Observation was one of the techniques which was used in collecting the data.

\section{d. Reflection}

After carrying out the process using Snakes and Ladders, the researcher and collaborator recited the result of the activities which occurred in classroom as the reflection of the action. They evaluated the process and the result of the implementation of Snakes and Ladders in speaking class. It was a basic consideration to make plan and to conduct the next meeting.

2. Data Collecting Technique

To support this research, researcher completes the data collecting procedure by using questionnaire, interview, test and observation.

a. Distributing Questionnaire

Questionnaire is a set off questions provided to obtain responses indirectly as it is occurred in non-face-to-face situation. It was given in the form of written questions with available answers in ranged-degree. It was aimed to know the students' personal problem faced in speaking. The researcher used questionnaire in the preliminary research and the end of the implementation.

b. Doing Observation

In this research, the researcher would observe and made diary while the observer would make field notes of all activities done in the process of teaching and learning speaking skill through Snakes and Ladders. In doing the observation, the researcher was helped by his collaborator. The function of collaborator here was to observe, evaluate and give suggestion about the implementation of Snakes and Ladders.

c. Giving Test

The researcher conducted oral tests of speaking skill. There were a pre-test and posttest which were used to collect the data. The researcher chooses this test because there are some advantages. To get the instrument validity and reliability in speaking skill test, the researcher used IBM SPSS version 22 for windows.

3. Data Analyzing Technique

After collecting the data, the researcher classified the data into two groups as follows:

a. Analyzing Quantitative Data

Improving the Students' Speaking Skill Through

Snakes and Ladders (S1) on Second Semester

Students of English Study Program at Stain Bengkalis

Rini Fitria1 Ervina 2 
P-ISSN: 2301-9913, E-ISSN: 2597-9132

DOI: http://dx.doi.org/10.31000/globish.v7i2

The classroom action research in this study would be successful if there was an improvement or enhancement of students' speaking skill. It could be shown when the students could do the test, felt easy and enjoyed learning in the classroom. After the data were collected, the researcher analyzed the scores from those tests by calculating the mean of pre-test and the post-test by using descriptive statistics. The researcher used it to answer whether there was difference between students speaking skill before and after the action.

The mean or average is computed by adding a list of scores and then dividing by the number of the score. The mean of the pre-test and post-test can be calculated with the formulas as follows:

$$
\begin{aligned}
& \bar{X}=\frac{\sum X}{N} \\
& \bar{Y}=\frac{\sum Y}{N}
\end{aligned}
$$

Where: $\bar{X} \quad=\quad$ means of pre-test scores

$\bar{Y}=\quad$ means of post-test scores

$N=\quad$ the number of samples

b. Analyzing Qualitative Data

To analyze the qualitative data, the researcher applied Interactive Model of Data Analysis as propounded by Matthew B. Miles and A.M. Huberman (1992). This model includes four different interconnected process: data collection, data reduction, data display and conclusion drawing and verification.

\section{Discussions}

The discussion is focused on using Snakes and Ladders in the teaching learning of Speaking Skill at STAIN Bengkalis. In this process identified some factors causing the low achievement of students' speaking skill. The factors came from the lecturer and students. First, most of the students may feel isolated. In other words, the researcher can say that the students are hopeless to do the task given. They are lazy to enter the class room because they are studying English by textbook and doing the task most of the time. Secondly, most students are shy and unwilling to speak. The speaking practice is limited to activities in the written form. Thirdly, the students have low interest in speaking English. It does not mean that they do not have ability to express their ideas, but they are not accustomed to speaking English. Consequently, when they are speaking, they cannot speak fluently.

After implementing the action in the first and second cycle, some points can be taken, there were:

1. The Improvement of Learning Atmosphere.

Teaching speaking through Snakes and Ladders made the students made easier to understand the content of the conversation. They became more active in learning speaking. They showed their contribution in the discussion and participated well in the teaching learning process by giving some opinion and asking some information they did not know. They enjoyed joining the lesson and confident.

2. The Improvement of Students' Speaking Skill

From the tests, it could be concluded that Snakes and Ladders could improve the students' speaking skill. Reticent students feel encouraged to speak because the ground 
rules have created an environment that promotes participation by all. There were some indicators which showed that there was an improvement in their speaking skill. They were:

1) Accent (pronunciation)

2) Grammar

3) Vocabulary

4) Fluency

5) Comprehension

6) The students' speaking scores improve from cycle 1 to cycle 2 which can be seen on the following table, although the improvement just a very little bit improvement.

The Mean Scores of the test

\begin{tabular}{c|c} 
Test & Mean Score \\
\hline Pre-test & 41.16 \\
\hline Post-test cycle 1 & 46.21 \\
\hline Post-test cycle 2 & 48.98
\end{tabular}

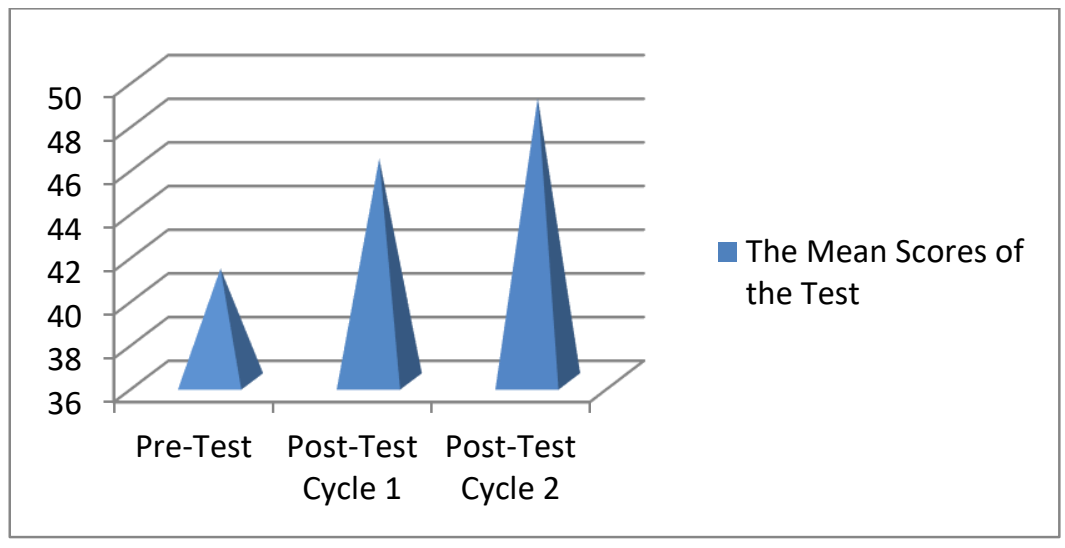

From the table above showed that there was an improvement of students' test result before and after the action. Although the improvement just a very little bit improvement. It was proved by increase of the students' mean score from 41.16 in the pre-test to 46.21 in post-test cycle l, and 48.98 in cycle 2.

\section{Conclusion}

After the researcher did the action research by using Snakes and Ladders, it can be drawn conclusion as follows:

1. Snakes and Ladders can improve the learning atmosphere. The learning atmosphere becomes more active and confident.

2. The Snakes and Ladders can improve students' speaking skill. It was proven by the increase of the students' mean score from 41.16 in pre-test to 46.21 in cycle 1 , and 48.98 in cycle 2. Although the results of the research were just a little bit improvement, but the researcher appreciated the students' hard work following the research.

Improving the Students' Speaking Skill Through

Snakes and Ladders (S1) on Second Semester

Students of English Study Program at Stain Bengkalis

Rini Fitria1 Ervina 2 
P-ISSN: 2301-9913, E-ISSN: 2597-9132

DOI: http://dx.doi.org/10.31000/globish.v7i2

\section{Reference}

Brown, Douglas. H. 1994. Teaching by Principles: An Interactive Approach to Language Pedagogy. United States of America: Prentice-Hall, Inc.

2000. Teaching by Principles: An Interactive Approach to Language Pedagogy, Second Edition. United States of America: Pearson Education, Inc

2007. Principles of Language Learning and Teaching. United States of America: Pearson Education, Inc

Celce, Marianne and Murcia. 2001. Teaching English as a Second or Foreign Language (Third Edition). The United States of America: Thomson Learning Inc.

Creswell, J W. 2008. Educational Research; Planning, Conducting, and Evaluating Quantitative and Qualitative Research, Third Edition. New Jersey: Pearson Education, Inc.

Cohen, L, et al. 2000. Research Method in Education: Fifth Edition. London: Routledge Falmer.

Haryati, S. 2012. The Use of "The Snakes and ladders Game" to Improve the Vocabulary Mastery: A Case of the Seventh Grade of SMP N 20 Semarang. A Thesis. Semarang: English Education Department, Faculty of Languages and Arts Education, IKIP PGRI Semarang.

Kemmis, S., and MacTaggart, R. 2005. Participatory Action Research: Communicative Action in the Public Sphere. In Denzin, Norman K. and Lincoln, Yvona S., (esd.) The SAGE handbook of Qualitative Research. 3rd ed. London: SAGE Publications.

Kusrini, E. (2012). Teaching Vocabulary For Junior High School Students Using Snake and Ladder Board Game. Purwokerto: Muhammadiyah University of Purwokerto. Pg. 3.

Linn, R.L and Grounlund, N.E. 2000. Measurement and Assessment in Teaching. Ohio: Prentice-Hall, Inc.

Luoma, S. 2004. Assessing Speaking. United Kingdom: Oxford University Press

Miles, Matthew and Huberman, A. Michael. 1992. Analisis Data Kualitatif: Buku Sumber tentang Metode-Metode Baru. Jakarta: UI Press

Pratama, Riogy Jakatayu and Satria, Ari. The Making of English Carrom Game to Improve Students' Speaking Skill for Junior High School. SNIT 2016; 483-490.

Rahmawati, I.N. 2012. Improving the Fourth Grade Students' Speaking Skill through Board Games at SD Muhammadiyah Pepe Bantul. A Thesis. Yogyakarta: English Education Department, Faculty of Languages and Arts, Yogyakarta State University. 
Simbolon, Novalina and Satria, Ari. 2016. Making Ludo Word Game (LWG) to Learn Grammar for Senior High School Students. Inovish Journal Vol 1 No 2: 77-85.

Teaching Speaking: Goals and Techniques for Teaching Speaking. Retrieved on March 03, 2019 at $5.50 \quad \mathrm{pm}$ from http://www.nclrc.org/essentials/speaking/goalsspeak.htms

Thornbury, Scott. 2005. How to Teach Speaking. Longman

Improving the Students' Speaking Skill Through Snakes and Ladders (Sl) on Second Semester Students of English Study Program at Stain Bengkalis Rini Fitria1 Ervina 2 